\title{
Immobilization of HRP Enzyme on Layered Double Hydroxides for Biosensor Application
}

\author{
Zouhair M. Baccar ${ }^{1}$ and Imène Hafaiedh ${ }^{2}$ \\ ${ }^{1}$ Nanobioengineering Group, National Institute of Research and Physicochemical Analysis (INRAP), Biotechnopôle de Sidi Thabet, \\ Sidi Thabet 2020, Tunisia \\ ${ }^{2}$ Unity of Research of Physico-Chemistry of Polymers, IPEST, University of Carthage, BP 57, La Marsa 2075, Tunisia
}

Correspondence should be addressed to Zouhair M. Baccar, zouhair_baccar@topnet.tn

Received 20 May 2011; Revised 9 June 2011; Accepted 11 June 2011

Academic Editor: Farnoush Faridbod

Copyright ( 2011 Z. M. Baccar and I. Hafaiedh. This is an open access article distributed under the Creative Commons Attribution License, which permits unrestricted use, distribution, and reproduction in any medium, provided the original work is properly cited.

\begin{abstract}
We present a new biosensor for hydrogen peroxide $\left(\mathrm{H}_{2} \mathrm{O}_{2}\right)$ detection. The biosensor was based on the immobilization of horseradish peroxidase (HRP) enzyme on layered double hydroxides- (LDH-) modified gold surface. The hydrotalcite LDH $\left(\mathrm{Mg}_{2} \mathrm{Al}\right)$ was prepared by coprecipitation in constant $\mathrm{pH}$ and in ambient temperature. The immobilization of the peroxidase on layered hybrid materials was realized via electrostatic adsorption autoassembly process. The detection of hydrogen peroxide was successfully observed in PBS buffer with cyclic voltammetry and the chronoamperometry techniques. A limit detection of $9 \mu \mathrm{M}$ of $\mathrm{H}_{2} \mathrm{O}_{2}$ was obtained with a good reproducibility. We investigate the sensitivity of our developed biosensor for $\mathrm{H}_{2} \mathrm{O}_{2}$ detection in raw milk.
\end{abstract}

\section{Introduction}

Horseradish peroxidase (HRP) is a glycoprotein with four lysine residues for conjugation to a labeled molecule. It produces a colored, fluorimetric, or luminescent derivative of the labeled molecule when incubated with a proper substrate, allowing it to be detected and quantified. Horseradish peroxidase was often used in conjugates to determine the presence of a molecular target and was also commonly used in techniques such as ELISA and Immunohistochemistry. Horseradish peroxidase is ideal in many respects for these applications because it is smaller, more stable, and less expensive than other popular alternatives such as alkaline phosphatase. Conductor's polymers and magnetic nanoparticles were used in the fabrication of various types of HRP-based biosensors $[1,2]$. To stabilize the immobilized enzyme in the matrix of film, glutaraldehyde (GA) is usually employed as a bifunctional agent to cross-link enzyme molecules [3-6], but the cross-linking efficiency under standard conditions is not always satisfactory $[6,7]$, which results in the lower sensitivity and poor stability of the resulting biosensor. It was established that cationic clays and especially anionic ones or layered double hydroxides were considered as a new class of materials with a high trapping potential of molecules of different sizes and that they form hybrid materials. Indeed, these materials present very attractive advantages such as a low cost of purification or synthesis and their biocompatibility. Furthermore, the bi-dimensional structure of LDHs with the general formula: $\left[\mathrm{M}_{1-X}^{2+} \mathrm{M}_{X}^{3+}(\mathrm{OH})_{2}\right]^{x+}$. $\left[\mathrm{A}_{x / q}\right]^{q-} \cdot n \mathrm{H}_{2} \mathrm{O}[8,9]$ present additional advantages relatively to cationic clays. LDHs can be synthesized using the same protocol, and the obtained materials have a large range of physicochemical properties. A wide varieties of $\mathrm{LDHs}$ can be achieved by changing the anionic ion $\mathrm{A}\left(\mathrm{CO}_{3}{ }^{2-}, \mathrm{SO}_{4}{ }^{2-}\right.$, $\mathrm{HPO}_{4}{ }^{2-}, \mathrm{NO}_{3}{ }^{-}, \mathrm{F}^{-}, \mathrm{Cl}^{-}, \mathrm{Br}^{-}$, and $\left.\mathrm{I}^{-}\right)$or the metallic divalent $\left(\mathrm{M}^{2+}: \mathrm{Mg}, \mathrm{Zn}, \mathrm{Ni}, \mathrm{Co}, \mathrm{Pd}\right.$, etc.) or trivalent ions $\left(\mathrm{M}^{3+}: \mathrm{Al}, \mathrm{Cr}, \mathrm{Fe}, \mathrm{V}\right.$, etc. $)$. This type of material presents high anionic-exchanging capacities by changing the divalent and trivalent ion ratio $\left(x=\left[\mathrm{M}^{2+}\right] /\left[\mathrm{M}^{3+}\right]\right)$ and adjusting the interlayer anions $\left[\mathrm{A}_{x / q}\right]^{q-}$ to intercalate different molecules [3-10]. Therefore, this kind of materials can be considered very attractive for new hybrid biomaterials development and for functionalized surfaces for ionic and biologic detection [10-12]. It has been previously shown that immobilization 


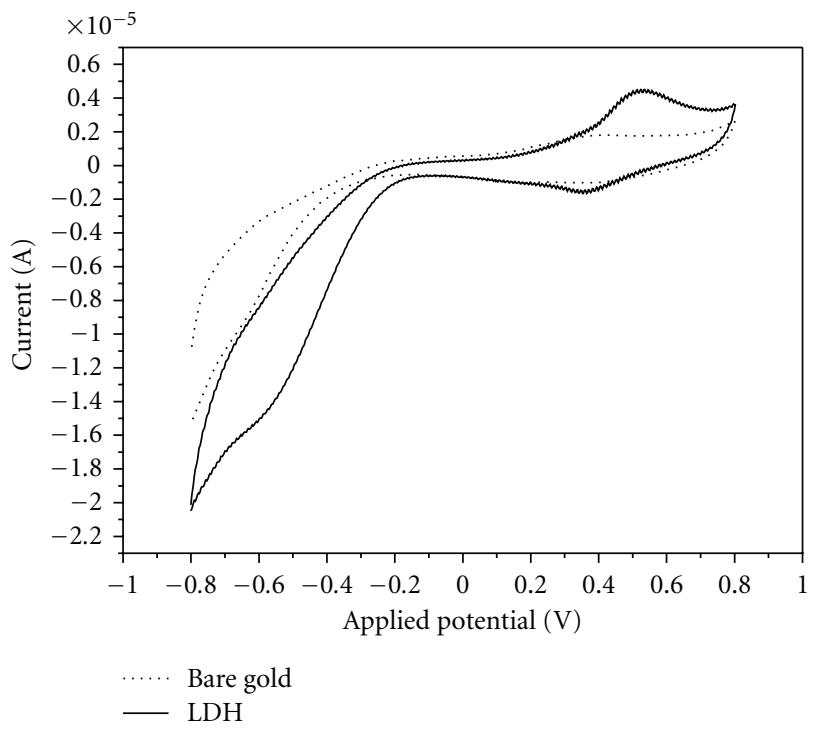

(a)

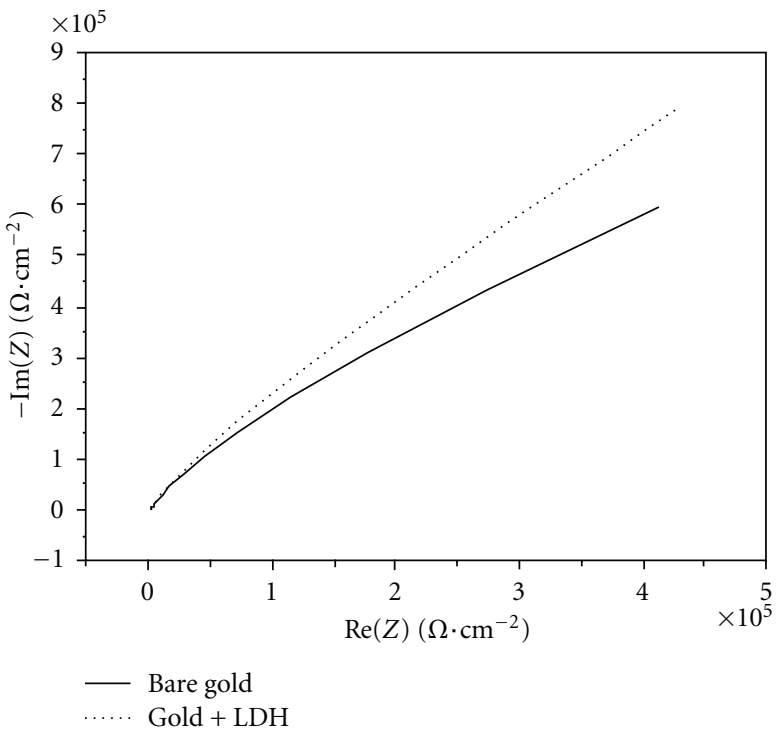

(b)

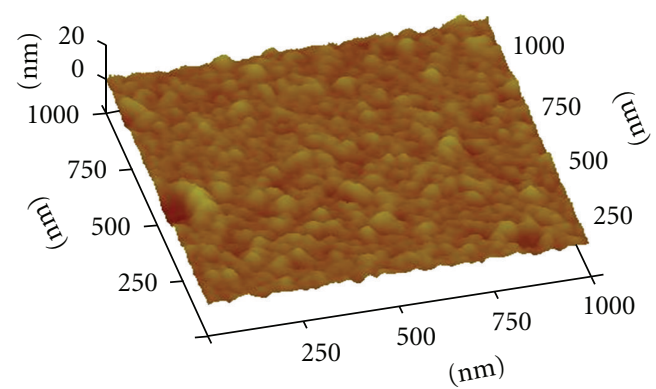

(c)

FIGURE 1: (a) Cyclic voltammetry measurement in PBS buffer of bare gold electrode and gold electrode with LDH, respectively. (b) Nyquist diagram $\left(Z_{i}\right.$ versus $Z_{r}$ ) of impedance measurement corresponding to the gold electrode without and with LDH layer. (c) Atomic force microscopy photo of gold surface treated with LDH. It shows a homogenous surface with roughness below $1 \mathrm{~nm}$.

of urease in LDH is of high interest for the fabrication of biosensors [12]. The panel of applications of these materials is very large; they can be used for monitoring food process, diagnosis and medical monitoring, or for therapeutic and pharmaceutical applications such as the encapsulation of active molecules for drugs [13-15] or radioactive substances.

In this work, we present a new biosensor for hydrogen peroxide $\left(\mathrm{H}_{2} \mathrm{O}_{2}\right)$ detection based on layered double hydroxides (LDH) layer. The biosensor was based on the immobilization of horseradish peroxidase (HRP) enzyme on $\mathrm{LDH}$-modified gold surface. The hydrotalcite $\mathrm{LDH}\left(\mathrm{Mg}_{2} \mathrm{Al}\right)$ was prepared by coprecipitation in constant $\mathrm{pH}$ and in ambient temperature. The immobilization of the peroxidase in layered hybrid materials was realized via electrostatic adsorption autoassembly process. The detection of hydrogen peroxide was successfully observed in PBS buffer with cyclic voltammetry and the chronoamperometry techniques.

\section{Experimental Setup}

2.1. Reagents and Apparatus. The hybrid biomembranes Enzyme/LDH were prepared in two steps: the LDH synthesis, followed by the peroxidase immobilization. We synthesized hydrotalcite LDH by coprecipitation method at constant $\mathrm{pH}$ and temperature. The ratio volume of solutions of $\mathrm{MgCl}_{3}$ and $\mathrm{AlCl}_{3} 0.1 \mathrm{M}$ was fixed at 2 in order to obtain a final LDH of $\mathrm{Mg}_{2} \mathrm{AlCO}_{3} . \mathrm{Mg}_{2} \mathrm{AlCO}_{3} \mathrm{LDH}$ was prepared according to the process described by Baccar et al. [16]. We added drop to drop and under vortex agitation the solution of $\mathrm{AlCl}_{3}$ and the $\mathrm{MgCl}_{2}$. The $\mathrm{pH}$ reaction of coprecipitation was fixed at $\mathrm{pH} 8$ by adding a basic solution of $\mathrm{NaOH}\left(\mathrm{NaOH} 2 \mathrm{M}+\mathrm{Na}_{2} \mathrm{CO}_{3}\right.$ $0.125 \mathrm{M})$. The final solution obtained was washed with milliQ water and filtered to eliminate the ions chlorides, then dried at $100^{\circ} \mathrm{C}$ in dark during 12 hours, and finally crushed.

2.2. Gold Cleaning and Functionalization. The gold electrodes $(1 \mathrm{~cm} \times 1 \mathrm{~cm})$ were fabricated at the National Center of Microelectronics of Barcelona (Spain). Evaporated gold ( $\sim 300 \mathrm{~nm}$ thickness) was deposited on silicon, using a titanium under layer ( $\sim 30 \mathrm{~nm}$ thickness) as substrate. Before modification, the gold electrodes were cleaned in acetone solution for $20 \mathrm{~min}$ with ultrasonic bath. After that, they were dried under a nitrogen flow and then dipped for $10 \mathrm{~min}$ into "piranha solution" $7: 3(\mathrm{v} / \mathrm{v}) 96 \% \mathrm{H}_{2} \mathrm{SO}_{4} / 30 \% \mathrm{H}_{2} \mathrm{O}_{2}$. 


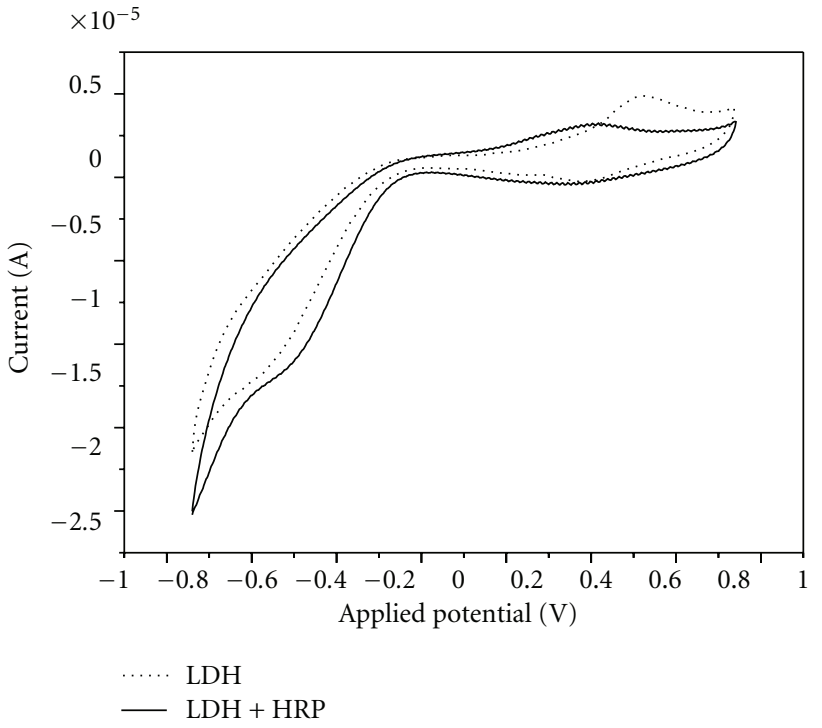

(a)

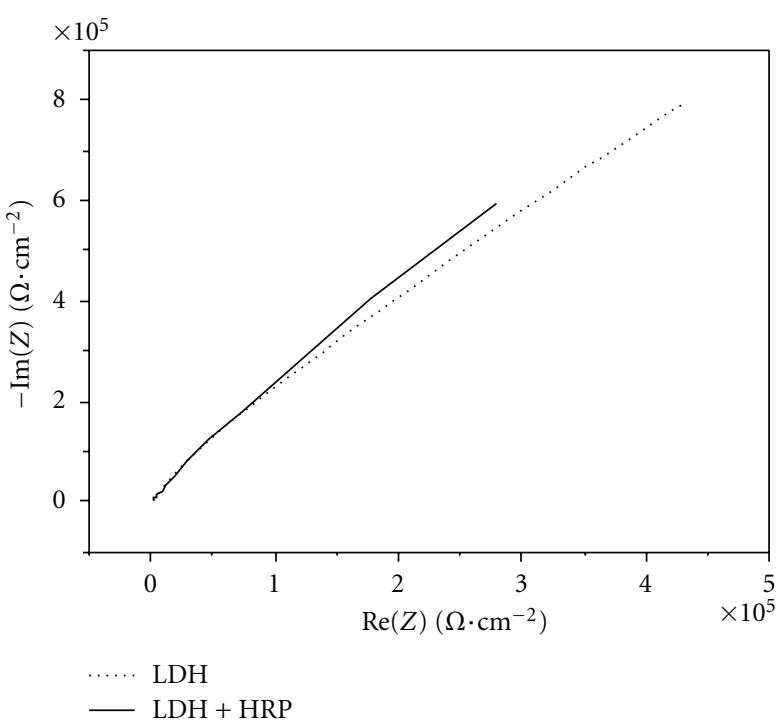

(b)

FIGURE 2: (a) Cyclic voltammogram of gold electrode functionalized with LDH before and after HRP immobilization. (b) Nyquist diagram $\left(Z_{i}\right.$ versus $Z_{r}$ ) of impedance measurement corresponding to the gold-electrode with LDH before and after HRP immobilization.

Finally, the gold substrates were rinsed 2 to 3 times with ultrapure water and immediately immersed in an ethanol solution. After cleaning, the gold electrodes were immediately placed on an electrochemical cell. For DHL deposition on gold electrodes, a drop (approximately $10 \mu \mathrm{L}$ by $\mathrm{cm}^{2}$ ) of dispersed $\mathrm{LDH}\left(\mathrm{Mg}_{2} \mathrm{Al} 2.5 \mathrm{mg} / \mathrm{mL}\right)$ in deionised water (milli-Q) was deposited and coated by spin coating at less than $1000 \mathrm{rms} / \mathrm{min}$ during $10 \mathrm{~s}$ and about $4000 \mathrm{rms} / \mathrm{min}$ during $30 \mathrm{~s}$. After that, a drop (approximately $10 \mu \mathrm{L}$ by $1 \mathrm{~cm}^{2}$ ) of HRP (equal to $0.250-0.330$ Units) dispersed in milli-Q water was deposited in surface and dried at $4{ }^{\circ} \mathrm{C}$ overnight. Finally, the nonbounded enzymes were eliminated by washing samples with a solution of $20 \mathrm{mM}$ PBS. After testing, the samples were stored in a solution of $20 \mathrm{mM}$ PBS, $\mathrm{pH} 7.4$ at $4^{\circ} \mathrm{C}$.

2.3. Cyclic Voltammetry and Chronoamperometry. Cyclic voltammetry and chronoamperometry measurement were performed at room temperature in a conventional voltammetric cell with a three-electrode configuration using Autolab impedance analyzer (Eco Chemie, The Netherland). The gold electrode $\left(0.16 \mathrm{~cm}^{2}\right)$ was used as working electrode and platinum $\left(1 \mathrm{~cm}^{2}\right)$ and $\mathrm{Ag} / \mathrm{AgCl}$ electrodes were used as counter and reference electrodes, respectively. All cyclic voltammetry measurements were carried out with scan rate of $75 \mathrm{mV} / \mathrm{s}$ in PBS at pH 7 and in Faraday cage. More details can be found in [17].

2.4. Atomic Force Microscopy and Impedance Spectroscopy. Atomic Force microscopy was performed using a Dimension 3100 (Veeco) Atomic Force Microscope operating in tapping mode. The impedance analysis was performed with the Autolab $302 \mathrm{~N}$ impedance analyzer (Eco Chemie, The Netherland) in the frequency range $0.05 \mathrm{~Hz}-100 \mathrm{kHz}$, using a modulation voltage of $10 \mathrm{mV}$. More details on electrochemical impedance spectroscopy can be found in [18-20].

\section{Results and Discussions}

3.1. Gold Electrode Functionalization. Cyclic voltammetry is an electrochemical technique which can be used to study the kinetic of redox reactions of materials, their insulating and conducting properties. Cyclic voltammograms of the gold electrode (Figure 1(a)) show a reversible wave which is the typical behavior of gold surface in PBS buffer. After modification of the gold surface with the LDH membrane, the current increases due to the high conductivity properties of the LDH layer and anion exchange (Figure 1(a)). Typical Nyquist plots for gold electrode and gold electrode with LDH layer from $50 \mathrm{mHz}$ to $100 \mathrm{KHz}$ at $0.2 \mathrm{~V}$ potential (versus Calomel electrode) in PBS were shown in Figure 1(b). Impedance spectra were interpreted through equivalent circuits representing the different processes involved in the description of the system with discrete electric elements [20, 21]. The semicircle diameter of impedance spectra represents the charge transfer resistance, $R_{\mathrm{ct}}$. This resistance controls the electron transfer kinetics of the ions at the electrode interface. Figure 1(c) shows the atomic force microscopy image of gold surface treated with LDH in tapping mode. It shows a homogenous surface with roughness less than $1 \mathrm{~nm}$. The same observation was observed with scanning electron microscopy (SEM) in [22].

3.2. HRP Immobilization. Figure 2(a) shows the cyclic voltammogram of gold electrode functionalized with LDH layer before and after HRP immobilization. We observe a decrease of the current for positive potential after HRP immobilization. The peak at $350 \mathrm{mV}$ corresponds to the oxidation 


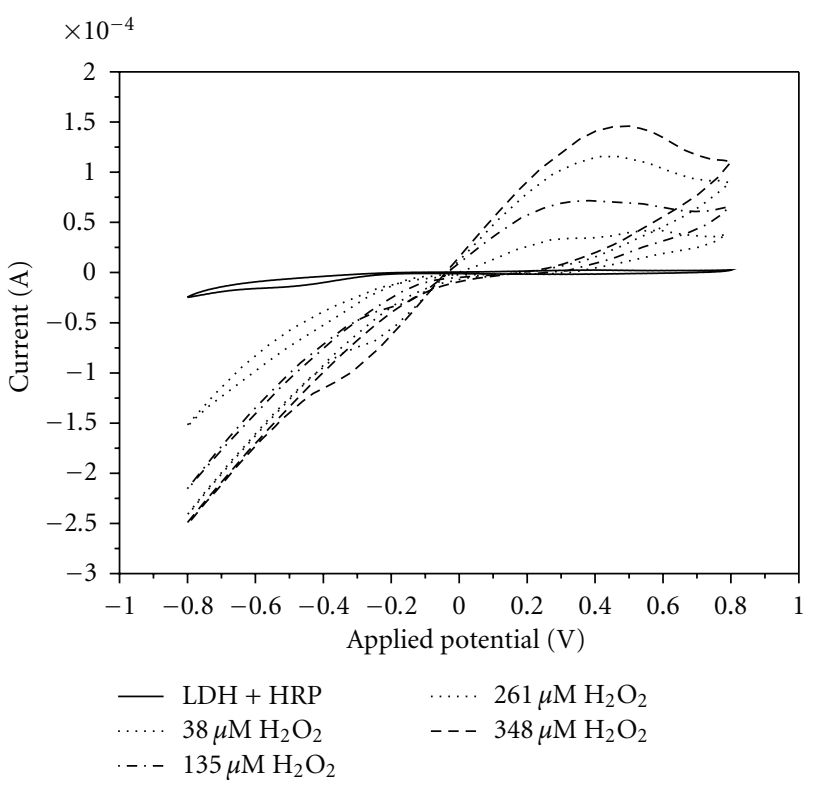

(a)

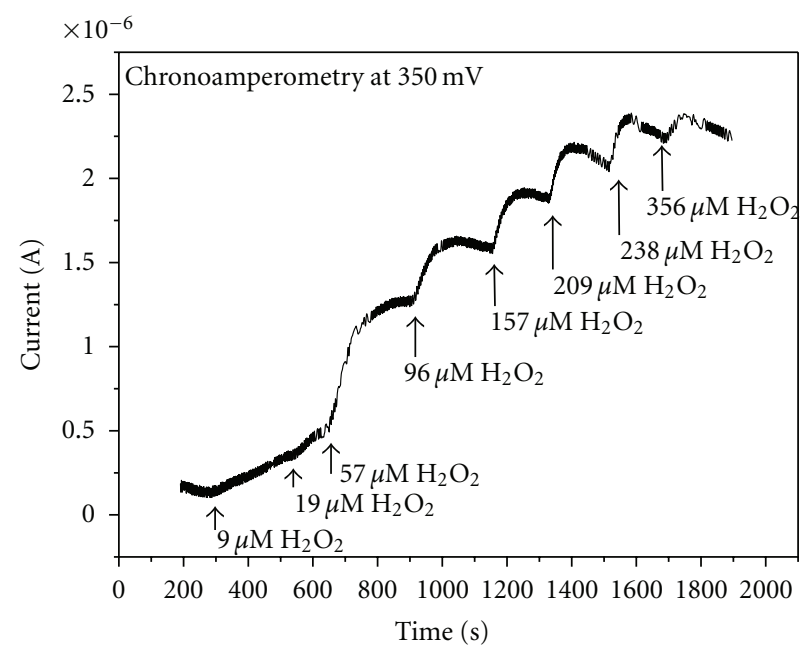

(b)

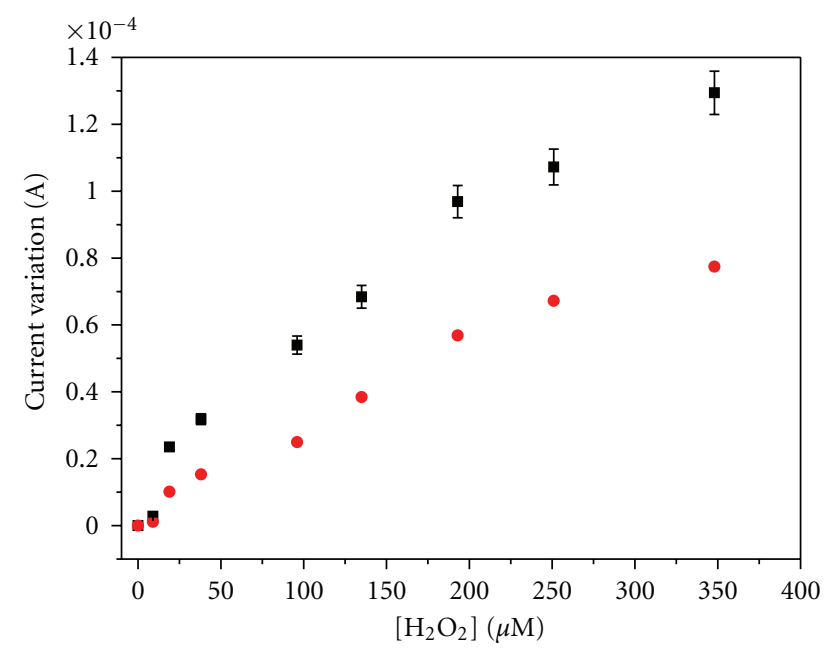

- Detection in PBS

- Detection in milk

(c)

FIGURE 3: (a) Cyclic voltammogram of gold electrode functionalized with HRP before and after the injection of different $\mathrm{H}_{2} \mathrm{O}_{2}$ concentration. (b) The chronoamperometry curve of functionalized gold electrode with $\mathrm{HRP}$ at a fixed potential of $350 \mathrm{mV}$ after $\mathrm{H}_{2} \mathrm{O}_{2}$ injections. (c) Current variation (current after $\mathrm{H}_{2} \mathrm{O}_{2}$ injection) of the developed biosensor after different injection of $\mathrm{H}_{2} \mathrm{O}_{2}$ concentration at $350 \mathrm{mV}$ obtained from Figure 3(a) in PBS buffer and raw milk. Linear regression was observed between 0 and $200 \mu \mathrm{M}$.

potential of HRP. Figure 2(b) shows the Nyquist diagram of impedance measurement at fixed potential $(0.2 \mathrm{~V})$ for gold electrode with LDH and with HRP enzyme. The increase of the charge transfer resistance is due to the success immobilization of the HRP enzyme. This result confirms the result obtained with cyclic voltammetry.

3.3. Biosensors Applications. Figure 3(a) shows the cyclic voltammogram of the gold electrode functionalized with HRP enzyme before and after injection of $\mathrm{H}_{2} \mathrm{O}_{2}$. Upon the addition of the hydrogen peroxide to the electrochemical cell, the oxidation peak (at $350 \mathrm{mV}$ ) appears, showing a typical electron transfer between the $\mathrm{H}_{2} \mathrm{O}_{2}$ and the HRP molecule:

$$
\begin{gathered}
\mathrm{H}_{2} \mathrm{O}_{2}+\mathrm{HRP}_{\text {red }} \longrightarrow \mathrm{HRP}_{\text {ox }}+\mathrm{H}_{2} \mathrm{O} \\
\mathrm{HRP}_{\text {ox }}+2 \mathrm{e}^{-} \longrightarrow \mathrm{HRP}_{\text {red }} .
\end{gathered}
$$

The chronoamperometry can be used to explore the current response of the biosensor in presence of the hydrogen peroxide. Figure 3(b) shows the chronoamperometry curve of functionalized electrode with HRP at a fixed potential of $350 \mathrm{mV}$ after $\mathrm{H}_{2} \mathrm{O}_{2}$ injections. The current increases with 
increasing $\mathrm{H}_{2} \mathrm{O}_{2}$ concentration which agrees with result shown in Figure 3(a). The addition of the hydrogen peroxide to the buffer solution increases the steady state current. Figure 3(c) shows the calibration curves of the biosensor exposed to different concentration of hydrogen peroxide obtained from Figure 3(a) (at a potential of $350 \mathrm{mV}$ ). The curves were represented by a linear regression (between 0 to $200 \mu \mathrm{M}$ ), and a best sensitivity was obtained. A limit detection of $9 \mu \mathrm{M}$ of $\mathrm{H}_{2} \mathrm{O}_{2}$ was obtained with a good reproducibility for the developed biosensor. Moreover, we investigate the sensitivity of our developed biosensor for $\mathrm{H}_{2} \mathrm{O}_{2}$ detection in raw milk. Figure 3(c) shows the calibration curve obtained in raw milk after $\mathrm{H}_{2} \mathrm{O}_{2}$ injection. It shows a lower sensitivity due to coexisting electroactive species such as casein (and other proteins) in raw milk.

\section{Conclusion}

In this work, we present new biosensors for the detection of hydrogen peroxide $\left(\mathrm{H}_{2} \mathrm{O}_{2}\right)$ with $\mathrm{LDH}$ functionalized layer. The biosensor was developed by the immobilization of horseradish peroxidase (HRP) enzyme on LDH-modified gold electrode. The deposition of LDH layer and HRP enzyme was verified with cyclic voltammetry and impedance spectroscopy. The detection of hydrogen peroxide was successfully observed in PBS using the cyclic voltammetry and the chronoamperometry techniques. A limit detection of $9 \mu \mathrm{M}$ of $\mathrm{H}_{2} \mathrm{O}_{2}$ was obtained with a good reproducibility. We investigate the sensitivity of our developed biosensor for $\mathrm{H}_{2} \mathrm{O}_{2}$ detection in raw milk.

\section{References}

[1] S. Helali, H. Baccar, A. Abdelghani, and N. Jaffrezic-Renault, "Electrochemical study of horseradish peroxidase biosensor based on functionalised magnetic beads and polypyrrole film," Sensor Letters, vol. 7, no. 5, pp. 808-811, 2009.

[2] C. C. Chen, J. S. Do, and Y. Gu, "Immobilization of HRP in mesoporous silica and its application for the construction of polyaniline modified hydrogen peroxide biosensor," Sensors, vol. 9, no. 6, pp. 4635-4648, 2009.

[3] K. Arora, G. Sumana, V. Saxena et al., "Improved performance of polyaniline-uricase biosensor," Analytica Chimica Acta, vol. 594, no. 1, pp. 17-23, 2007.

[4] V. Luo and J. S. Do, "Urea biosensor based on PANi(urease)Nafion/Au composite electrode," Biosensors and Bioelectronics, vol. 20, no. 1, pp. 15-23, 2004.

[5] A. H. Parente, E. T. A. Marques, W. M. Azevedo, F. B. Diniz, E. H. M. Melo, and J. L. L. Filho, "Glucose biosensor using glucose oxidase immobilized in polyaniline," Applied Biochemistry and Biotechnology, vol. 37, no. 3, pp. 267-273, 1992.

[6] I. Migneault, C. Dartiguenave, M. J. Bertrand, and K. C. Waldron, "Glutaraldehyde: behavior in aqueous solution, reaction with proteins, and application to enzyme crosslinking," BioTechniques, vol. 37, no. 5, pp. 790-802, 2004.

[7] K. F. Fernandes, C. S. Lima, H. Pinho, and C. H. Collins, "Immobilization of horseradish peroxidase onto polyaniline polymers," Process Biochemistry, vol. 38, no. 9, pp. 1379-1384, 2003.
[8] E. P. Giannelis, D. G. Nocera, and T. J. Pinnavaia, "Anionic photocatalysts supported in layered double hydroxides: intercalation and photophysical properties of a ruthenium complex anion in synthetic hydrotalcite," Inorganic Chemistry, vol. 26, no. 1, pp. 203-205, 1987.

[9] M. Meyn, K. Beneke, and G. Lagaly, "Anion-exchange reactions of layered double hydroxides," Inorganic Chemistry, vol. 29, no. 26, pp. 5201-5207, 1990.

[10] H. Barhoumi, A. Maaref, M. Rammah et al., "Urea biosensor based on Zn3Al-Urease layered double hydroxides nanohybrid coated on insulated silicon structures," Materials Science and Engineering C, vol. 26, no. 2-3, pp. 328-333, 2006.

[11] J. V. Melo, S. Cosnier, C. Mousty, C. Martelet, and N. JaffrezicRenaultt, "Urea biosensors based on immobilization of urease into two oppositely charged clays (Laponite and Zn-Al layered double hydroxides)," Analytical Chemistry, vol. 74, no. 16, pp. 4037-4043, 2002.

[12] Z. M. Baccar, S. Hidouri, A. Errachid, and O. Ruiz-Sanchez, vol. 11, Journal of Nanoscience and Nanotechnology. In press.

[13] B. Li, J. He, D. G. Evans, and X. Duan, "Inorganic layered double hydroxides as a drug delivery system-intercalation and in vitro release of fenbufen," Applied Clay Science, vol. 27, no. 3-4, pp. 199-207, 2004.

[14] M. Del Arco, S. Gutievreg, C. Martin, V. Rives, and J. Rocha, "Synthesis and characterization of layered double hydroxides $(\mathrm{LDH})$ intercalated with non-steroidal anti-inflammatory drugs (NSAID)," Journal of Solid State Chemistry, vol. 177, no. 11, pp. 3954-3962, 2004.

[15] S. Y. Kwak, Y. J. Jeong, J. S. Park, and J. H. Choy, "Bio-LDH nanohybrid for gene therapy," Solid State Ionics, vol. 151, no. 1-4, pp. 229-234, 2002.

[16] Z. M. Baccar, S. Hidouri, N. El Bari, N. Jaffrezic-Renault, A. Errachid, and N. Zine, "Stable immobilization of anti-beta casein antibody onto layered double hydroxides materials for biosensor applications," Sensor Letters, vol. 7, no. 5, pp. 647655, 2009.

[17] A. Tlili, A. Abdelghani, S. Ameur, and N. Jaffrezic-Renault, "Impedance spectroscopy and affinity measurement of specific antibody-antigen interaction," Materials Science and Engineering $C$, vol. 26, no. 2-3, pp. 546-550, 2006.

[18] M. Hnaien, S. Helali, M. F. Diouani et al., "Immobilization of specific antibody on SAM functionalized gold electrode for rabies virus detection by electrochemical impedance spectroscopy," Biochemical Engineering Journal, vol. 39, no. 3, pp. 443-449, 2008.

[19] H. B. Fredj, S. Helali, L. Vonna, L. Vidal, A. Abdelghani, and C. Esseghaier, "Labeled magnetic nanoparticles assembly on polypyrrole film for biosensor applications," Talanta, vol. 75, no. 3, pp. 740-747, 2008.

[20] M. F. Diouani, S. Helali, I. Hafaid et al., "Miniaturized biosensor for avian influenza virus detection," Materials Science and Engineering C, vol. 28, no. 5-6, pp. 580-583, 2008.

[21] S. Helali, A. Abdelghani, I. Hafaiedh, K. Cherifa, and G. Tournierb, "Characterization of tin dioxide film for chemical vapors sensor," Materials Science and Engineering C, vol. 28, no. 5-6, pp. 584-587, 2008.

[22] C. Mousty, O. Kaftan, V. Prevot, and C. Forano, "Alkaline phosphatase biosensors based on layered double hydroxides matrices: role of LDH composition," Sensors and Actuators, B, vol. 133, no. 2, pp. 442-448, 2008. 


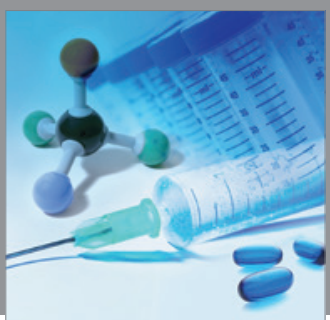

International Journal of

Medicinal Chemistry

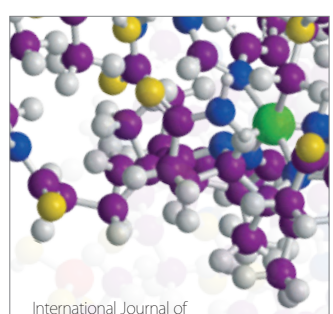

Carbohydrate Chemistry

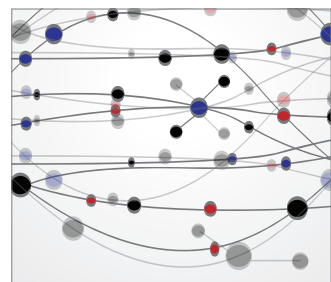

The Scientific World Journal
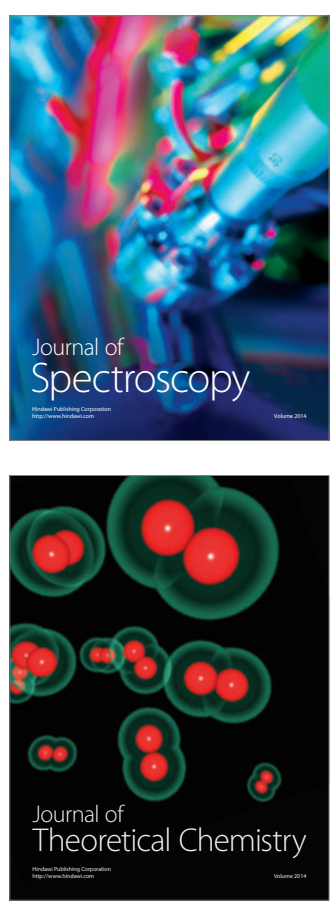
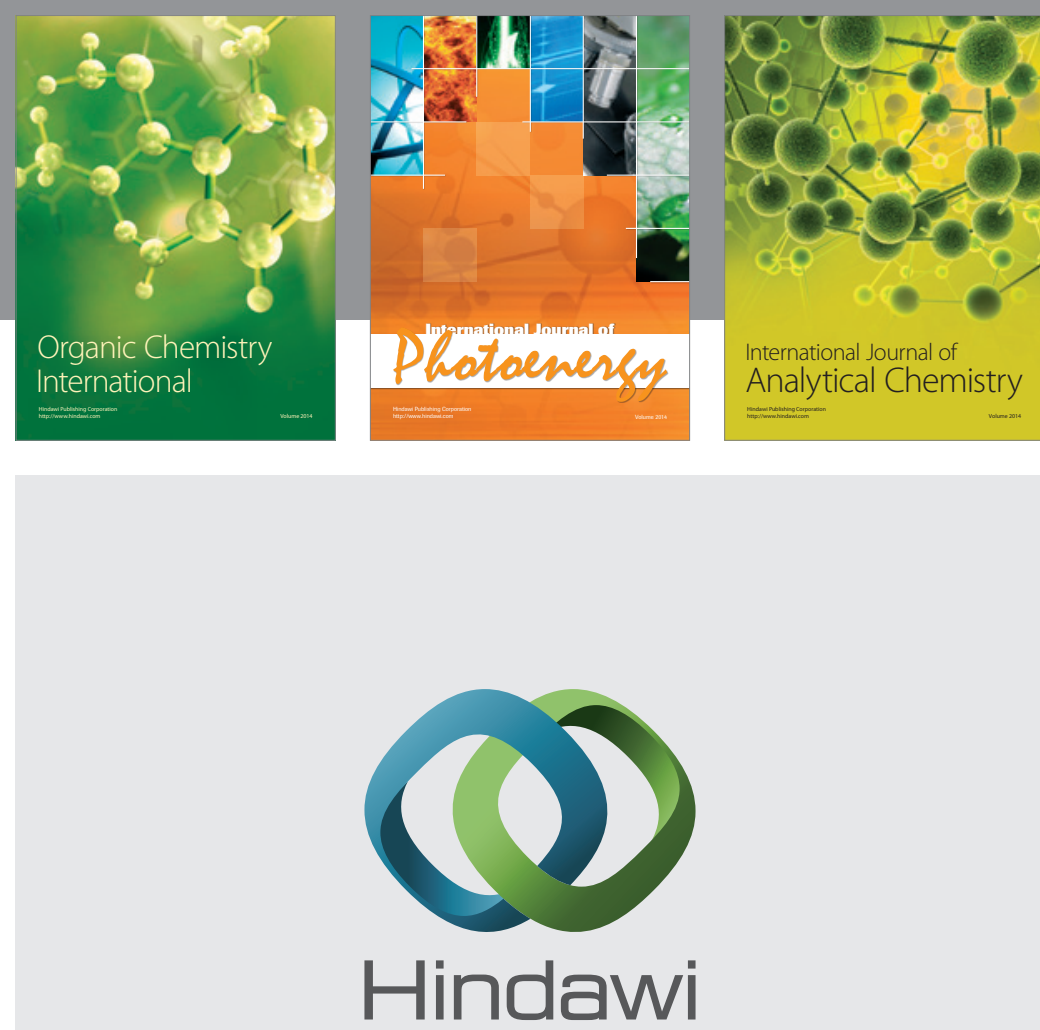

Submit your manuscripts at

http://www.hindawi.com
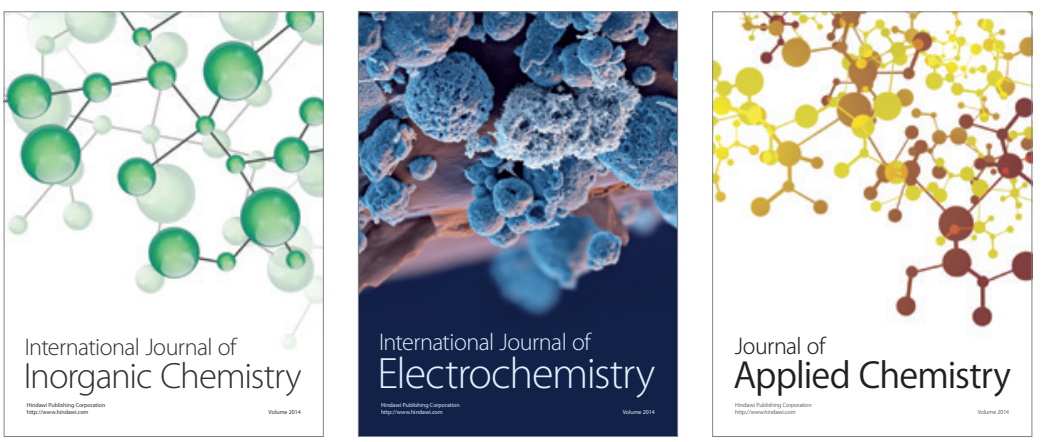

Journal of

Applied Chemistry
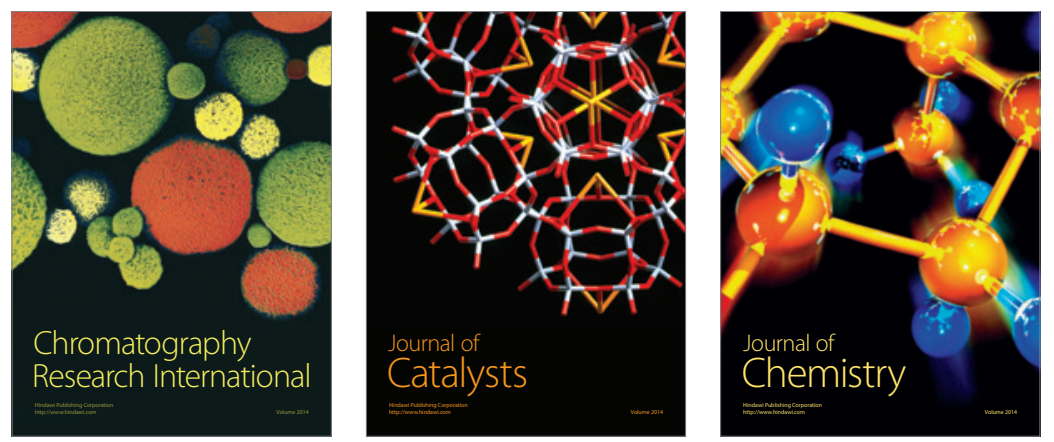
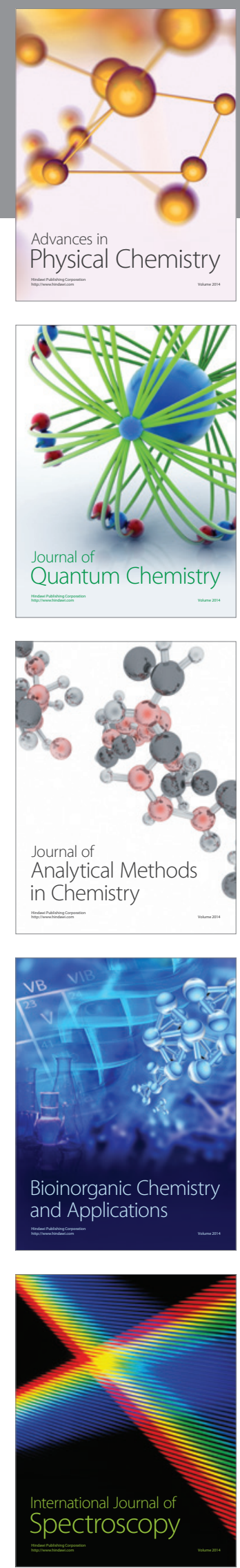